\title{
Authentic Leadership for Conducive Madrasa Climate
}

\author{
Aan Komariah \\ Universitas Pendidikan Indonesia \\ aan_komariah@upi.edu
}

\begin{abstract}
The main objective of this study is to assess the effect of Authentic Leadership to Madrasa (Senior High School) Climate in Public Madrasah and Private Madrasa Aliya (Islamic Senior High School) in Tasikmalaya Regency. This research was conducted by using descriptive and verification methods, with a quantitative approach. The populations are 73 Public and Private Madras Aliyah in Tasikmalaya regency, with headmaster, school committee, and teachers as data sources. Data were collected using a questionnaire and analyzed using correlation analysis. The results showed that the overall pictures of Public and Private Madrasah Aliyah in Tasikmalaya Regency were already high. The Principals Leadership affectson the Madrasa Climate. The recommendation is to improve madrasa by promoting the existence of madrasa leadership and other factors affecting on the madrasa climate, such as the improvement of madrasah facilities, learning strategy, use of learning media, and capacity development of continuous effective madrasa.
\end{abstract}

Keyword-Authentic Leadership, Madrasa Climate, Effective Madrasa

\section{INTRODUCTION}

Madrasah serves an important role in the students' moral establishment and its existence is still the main choice for parents making religion as the basic education for their children. In madrasa, students are directed to be more comprehensive field in intellectual, skill and moral aspects framed in strong spiritual. The madrasa is believed to be able to integrate religious maturity and modern science skills as well in the students. So, there are some determined people understanding on the madrasa world in maintaining the madrasa existencee. Aalso, the ones having interest on madrasa are encouraged by idealism values. Ideally, madrasa is able to present the great, beautiful and perfect Islamic teachings.

The orientation of quality improvement efforts in Madrasa Aliya education mainly can be done by improving the work climate growth from aauthentic madrasa leaders. From their words, the improvement of work climate is an urgent thing to be done in madrasa so that it can strengthen the leadership function by more authentic manners. The madrasa leaders are the trigger for the growth of conducive work climate encouraging for effective madrasa education quality [1] stated that the effective education institutions involve: (1) Strong Leadership; (2) A Clear Mission; (3) A Safe and Orderly Climate; (4) Monitoring Student progress; (5) High Expectation; (6) Teacher Performance; and (7) Society Participant.

Madrasa headmaster as the top leader serves a central role as agent of driver, dynamist and facilitator having ability to create conducive madrasa work climate. The climate is a healthy atmosphere bringing motivation in working and encouraging on the growth of participation and achievement. Madrasa headmaster builds the conducive work climate consciously and intensively by applying authentic leadership approach. The madrasa headmaster with strong legitimacy can create new conducive work climate to work and the relevant one to any changes and based on the values given by scholars.

\section{LITERATURE REVIEW}

The Authentic Leadershipis a type of leadership demanding on the leaders to act authentically. In The Authentic Leadershipis a leader having honesty to himself or herself [2]. Meaning that there is a harmony between behaviour and trust. To be an authentic leader [3] have a statement, "to become authentic, each of us has to develop our own leadership style, consistent with our personality and character". Having no consistency between what in ourselves, how it may be possible to be a true leader. The authentic leaders are consistent people and show their thought - utterance - actions.

By being a tough authentic leader, madrasa will be very lively, people in it will work enthusiastically, confident and powerful in doing any activities. An authentic leader will be a trigger for the growth of a conducive madrasaclimate. A leader identity is full with awareness to serve and make people to be calm, comfortable, peaceful and able to work with joy. Such leaders are trying to give to be a role model by working with high self-discipline to provide support, motivation, and create human relations with full familiarity. [4], suggested that there are five aspects of working environment, namely: Supportive, Collegial, Intimate, High spirit, and Low disengagement. These aspects are very attached to be created by an authentic leader. 
An authentic leader is able to synergize each job responsibility according to ability, and skills of members, as well as harmonize social interaction. This will lead to the creation of quality culture growing from each member self awareness. There is certainly a relationship between leadership and madrasa climate, where the climate is a factor related to the madrasa effectiveness built by conduciveclimate and work culture. [5]

Madrasa conducive climate is a barometer for healthy interpersonal relationship built by leaders. Because the climate of madrasa atmosphere created by interpersonal relationship pattern between teachers and teachers, teachers and school leaders or vice versa leaders with teachers. All of these come on how leaders build good relationships, mutual respect and appreciation. Madrasa climate is a quality of madrasa environment where there are continuously teachers on the physical environment and non-physical works creating comfort and satisfaction at work [6].

Healthy climate is one thing playing a role in creating a constructive culture. But, the climate is certainly not always healthy, so the unhealthy climate affect on other cultures as well. Any organizationalmembers with high motivation and a good sense of empathy among other organizational members will affects on other organization members. Thus, other organizational members will also be motivated and start to have empathy among organizational members. Here, there is an authentic leader's role to encourage impressive empathy in daily life, so that the madrasa working climate will be the conducive working climate.

\section{METHODOLOGY}

The research done in Tasikmalaya Regency in Madrasa Aliyah (Islamic Senior High Schools), highlights on the authentic leadership and madrasa climate factors as the main study of effective madrasa. There are 73 madrasas as the unit's analysis with Probability Sampling method and Stratified Sampling technique. The questionnaires are the tool to obtain data by 5 assessment criteria, namely (1) to be never done, (2) to have once done, (4) often to be done, and (5) to be accustomed to be done. The data processing is done quantitative descriptive trying to describe an illustration on all aspects of each variable stated by percentage and by correlation analysis.

The authentic leadership of madrasa headmaster is a driver variable, which can empower all madrasa resources and components to realize the madrasa purposes productively based on the predetermined provision. There are six authentic leadership aspects adapted from various experts, namely (1) Vision and Purpose-Oriented, (2) High self-discipline, (3) Moral and aesthetic values-based, (4) self awareness in leadership skills, (5) Balancing Processing,

(6)
Transparency Relationship, (7) Building Nnetwork. [7], [8], [9].

While the madrasa climate is an environment affecting on madrasa people by feeling secure, clean, comfortable and supporting on teaching and learning process as well as can support the students to participate on organizational aspects and madrasa life, consisting of sub-variables: (1) Supportive, (2) Intimate, (3) Collegial, (4) High spirit, and (5) Low disengagement. [10]

\section{RESEARCH RESULTS AND DISCUSSION}

The authentic leadership consists of six aspects, namely 1) Vision and Purpose-Oriented, (2) High selfdiscipline, (3) Moral and aesthetical values-based, (4) self awareness in leadership skills, (5) Balancing Processing, (6) Transparency Relationship, (7) Building network. Based on the percentage of each aspect achievement, an authentic leader is built on high self-discipline, self-awareness in leadership skills, and efforts in building network, based on moral and ethical values by strengthening solid relationships and work openness in achieving goals.

Research finding on madrasa authentic leadership reinforces. The importance of hard work as an embodiment of a authentic leader. Visually, what in the surface and daily life as the leader identity is one display that is constantly busy doing work programs. These findings are almost exactly the same as Komariah study [11] stating that hard work is the unique character of an authentic leader. In complete, the Behavior / Self Discipline is the most important aspect of authentic leadership, followed by Transparency, Ethical / Moral, relationship, Vision and Self Awareness

The authentic leader is seen as a person with high integrity and a strong commitment to make any progress for the madrassa, this is in line with George's opinion, 2014, stated that the authentic leader is a leader with very high integrity in building organizational commitment; a leader with determination to goals to be achieved from the organizational core values which he believes in. An authentic leader isa leader promoting on moral and character-based leader.

There are five aspects of madrasa climate, namely (1) Supportive, (2) Intimate, (3) Collegial, (4) High spirit, and (5) Low disengagement. The most interesting thing is on the lowest percentage namely the intimacy, though it has a high percentage on supportive and collegiality. This shows that the supportive and collegialityshown do not illustrate the intimacy of relation containing on the indicators of solidarity and cohesiveness as well assense of belongingness. Headmaster should be more concerned to build a sense of belonging and teamwork since where basically they live and interact with the madrasa community.

Learning from the school climate proposed by Hoy, that the school climate is the overall school quality 
which is relatively resistant by a group, describes on behavior perceptions, and affects on attitudes and behavior at school. [12] The school climate relates to the school quality in order to help every individual at school to feel self-appreciation, dignity and interests, while simultaneously it helps to create a sense of belonging for something outside ourselves. The school climate can encourage resistance or be a risk factor in the lives of people working and learning in a place called as school. The reference puts a "sense of ownership", as an important element to be a reflection of the conducive climate at school.

Hypothesis testing results show that there are authentic leadership contributions to the madrasa climate, which is $34.09 \%$ in the medium category. With the $t$ value of $12.3931>$ table $=1.9681$, we can conclude that the authentic leadership positively and significantly affects on the madrasa climate. The authentic leadership applied by headmaster through work discipline, with full awareness, networking, value-based, goal-oriented are actions that can build a conducive environment full of support, friendship and intimacy.

There is a finding showing an effect of leadership on the school climate expressed by Malmberg, etc. [13] Thehead teacher leadership has strong effects on the school climate. In practice, madrasa headmasters are necessary to consider on any factors building the conducive climate, namely: (1) quality of leadership, (2) amount of trust, (3) communication, upward and downward, (4) feeling of useful work, (5) responsibility, (6) reasonable controls, structure, and bureaucracy, and (7) employee environment, participation. [14]

\section{CONCLUSION}

Ideally, an authentic leadership by madrasa headmaster is built on high self-discipline, awareness in leadership skills, and attempting to build a network, based on moral and ethical values through strengthening on solid relationships and work openness in achieving goals. Factually, the leadership level has not become the identity of authentic leader by madrasa leaders. The constant and superior behavior is not identified and displayed to encourage followers to be a reference as a person with full of inspirations. The authentic self discipline appears in the form of compliance in conducting everyday tasks, compliance to the call of live as a Muslims in worship, doing any programs and applying human relation. New habits should be instilled by leader in performing its role as an authentic leader so that these can encourage a conducive climate. This can be done by applying authenticity of work relationship through impressive empathy principles to be able to encourage followers to feel sympathy and ultimately to be motivated to help and realize the common program.

The madrasa climate shows mutual interaction support, thick collegiality, low resistance and high motivation to conduct any tasks. But the intimacy aspect in term of showing solidarity and cohesiveness, a sense of belonging or a sense of agency must still be built strongly. An authentic leaderby self-awareness in building human relation and networks can focus on teamwork and a sense of belonging to the institutions.

There is positive and significant effects ofMadrasa authentic leadership on the madrasa climate, with medium contributions. This shows that madrasa leaders should implement the authentic leadership principles to achieve climate conducive, mainly focused on intimacy between people working in it.

\section{REFERENCE}

[1] Sadker, D.M. \&Zittleman, K., (2006). Teachers, Schools, and Society, McGraw-Hill. Humanities Social Sciences languages.

[2] May, D. R., Chan, A. Y. L., Hodges, T. D., \&Avolio, B. J. (2003). Developing the moral component of authentic leadership. Organizational Dynamics, 32, 247-260.

[3] George, Bill. (2003). Authentic Leadership; Rediscovering the Secrets to Creating Lasting Value. $6^{\text {th }}$ ed., USA: A Warren Bennis Book.

[4] Walumbwa, F. O., Avolio, B. J., Gardner, W. L., Wernsing, T. S., \& Peterson, S. J. (2008). Authentic leadership: Development and validation of a theory-based measure. Journal of Management, 34, 89-126.

[5] Stronge, H. James., Richard, B. Holly ., and Catano, Nancy. (2013). Qualities of Effective Principals. 1st Edition. New York: Association for Supervision \& Curriculum Development

[6] George, B. (2014). Authentic leadership: rediscovering the secrets to creating lasting value. Journal of the American College of Radiology: JACR, 11(5), 1-241. http://doi.org/10.1016/j.jacr.2013.11.002

[7] Komariah, Aan. (2012). Authentic Leadership KepalaSekolahDalamMenanamkanSistimNilai.JurnalllmuPend idikan, Jilid18 : 387-392. State University of Malang

[8] Hoy, W.K., \&Miskel, C.G. (2013). Educationaladministration: Theory, Research, andPractice. Ninth Edition. New York: McGraw

[9] Northouse, P. (2013). Leadership-Theory and Practice, Sixt Edition. UK: SAGE Publications Ltd.

[10] Hoy, W.K., \&Miskel, C.G. (2013). Educationaladministration: Theory, Research, andPractice. Ninth Edition. New York: McGraw

[11] Komariah, Aan. (2012). Authentic Leadership KepalaSekolahDalamMenanamkanSistimNilai.JurnalImuPend idikan, Jilid18 : 387-392. State University of Malang

[12] Hoy, W.K., \&Miskel, C.G. (2013). Educationaladministration: Theory, Research, andPractice. Ninth Edition. New York: McGraw

[13] Malmberg, Lars., Smees, Rebecca., Steele Fiona., Levacic, Rosalind. (2003). Paper Presented at British Educational Research Association Annual Conference, Heriot-Watt University, edinburgh.

[14] Davis, Keith, \& Jhon W. Newstrom, [2000]. Perilaku Dalam Organisasi, Edisi Ketujuh, Alih Bahasa Agus Darma, Jakarta: Erlangga 